\title{
Customer Participation Behaviors and Brand Loyalty Based on the Media Characteristics of Wechat
}

\author{
Hong JIN \\ School of Business, Jiangxi Normal University, Jiangxi, China \\ Guozhong LI \\ Faculty of Management and Economics, Kunming University of Science and Technology, Kunming, China
}

\begin{abstract}
The study analyzes the customer participation behaviors based on the media characteristics of Wechat-the mobile SNS tool when enterprises conduct promotion; and it pointed out that the special communication way of Wechat puts more emphasis on the importance of customer participation in China. Therefore, it can more effectively motivate the customer participation behaviors, improve the public relation effect and marketing performance of Wechat, and achieve the desired public relations purposes by correctly understanding and choosing the media characteristics. This research will explore the antecedents of customers' participative behaviors including from the perspective of consumers, and empirically analyzes the impacts of customers' participation on the behavioral results of brand loyalty. On this basis, the impact of customer participation behaviors on its brand loyalty is further explored, trying to provide theoretical enlightenment for the consumer participation strategies when enterprises develop the Wechat public relations platform.
\end{abstract}

KEYWORD: Customer Participation; Brand Loyalty Based; Wechat

\section{INTRODUCTION}

Wechat is the most representative mobile social networking application in domestic market. By the end of November 2013, the number of registered users has exceeded 600 million, including overseas users of over 100 million, and domestic users of over 400 million. Wechat has become the fifth most popular mobile application in the world after Google maps, mobile Facebook, YouTube and Google + mobile application (GlobalWebIndex, 2013). As a mobile social networking platform, Wechat is a newly-emerged way of public relations and marketing, and both government agencies and academic circles are still in the initial stages of the research on Wechat, and there are few researches on customer participation that Wechat marketing emphasizes. Recently, more and more enterprises and government departments have recognized the importance of customer participation in Wechat, and send public relations contents via the Wechat platform or whatever they could to attract customers to participate in this activities. For example, CCTV has introduced QR Code of Wechat; and local government departments and agencies have also launched their own Wechat platforms. However, Wechat instantly transfers information; the government information will be sent to the public without any omission. Though the timely arrival rate of high volume of information can bring high promotion value, it will very much likely be treaded as spam or virus marketing for improper usage (Goldsmith, 2002) such as too much information has been sent too frequently, or not updated in a timely manner, and thereby, customer participation is reduced. It is thus clear that Wechat-like mobile community has a higher requirements for customer participation enthusiasm than those of other general virtual social network communities, and how to evaluate and choose these methods to improve the level of customer participation from the perspective of media characteristic of Wechat is an important topic that needs further exploration.

\section{MOBILE SOCIAL NETWORKING AND WECHAT}

Role of mobile SNS. The foreign researches on mobile SNS platform are mainly focused on the individual application platforms. For example, Lipsman et al (2010) pointed out after analyzing the Facebook advertising types that the advertisings on Facebook had an important impact on improving enterprises' brand image, and stressed that the Facebook had made greater contribution to 
strengthening the market communication of enterprises(Lipsman, Mudd, Rich, and Bruich 2010). In addition, the social networking of mobile phonebased Twitter has an obvious, more rapid and more accurate advantage than the previous computer based social networking (Sun et al. 2011). The mobile SNS represented by Wechat (Wechat) in the domestic market is different from other Internet products and services because of the difference between public relations mode and sociability, thus it is necessary to conduct the exploration and analysis of its external influencing variables.

Application of Wechat. Nowadays, the Internet is experiencing its third high-speed development after the Web1.0 and Web2 reforms-real-time mobile network stage and the user's needs has become more diversified and personalized. As the China's first world-class mobile real-time SNS product, Wechat has shown the trend of leading the future development since it was first launched. It has become an important platform where the government agencies and enterprises could provide quality content, establish channels where users could communicate and interact with each other, and implement the public relations and marketing strategies. The diversified ways of information dissemination are highly valuable for both individuals' social activities and government's propaganda activities. From the social perspective, the function of voice chatting of Wechat has changed the traditional way people communicating via text messages; it can be operated across telecommunication carriers and operating system platforms, increase the number of people one is interested by the function of "shaking it off", which has extended users' social scope. From the perspective of government, communication between government and the target users could be conducted through the function of voice chatting, pictures, text and other forms of functions that Wechat provides, leading to a better public relations.

In addition, enterprises and public institutions can also diversify their ways of marketing for public relations by introducing "QR Code" and "online payment", send promotional information to hundreds of millions of the target user groups to attract their attention so as to establish the contact with them on line and interact with them offline, and make a better combination of online and offline development via Wechat.

\section{MAJOR MEDIA CHARACTERISTICS INFLUENCING CONSUMERS' PARTICIPATION IN WECHAT PROMOTION}

When used for promotion, the media characteristics of Wechat that influence the users' participation mainly include entertainingness of information pushing, the frequency of interaction with online users, etc. (1) Entertainingness: Entertainingness is based on an individual's subjectivity that usually leads to happiness or fun (1998 Perse). Basic Psychological Need Theory discusses that the meeting and an individual demand is the source of happiness; when the need is met, the individuals will feel joyful or happy (Omodei, and Wearing 1990). Jung et al. (2007) found through the study of Cyworld site users that entertainingness is the main reason for people to participate in Cyworld. Banczyk et al (2008) conducted the study on the factors influencing self-presentation of MySpace users, also found that communication and entertainingness are the main motivations for people to participate in the site activities. (2)Interaction: In virtual communities, the users interact with the moderator on various topics that they are interested in in order to obtain or contribute things that they think valuable (Song, George 2008). Liu and Shrum (2002) defined the interaction as the degree to which both sides of information commuters' impact on each other, media and information. Along with the shift from product-oriented logic to service-oriented logic, the users have gradually shifted from passive recipients to the co-creators of value. Accordingly, the interaction in the virtual networking becomes more frequent, and more important (Nambisan, and Baron 2009; Vargo, and Lusch 2004). Customers' satisfaction in pursuit of the participation is the newly emerged trend of users' demand in recent years, and the combination with anonymity, creativity, entertainingness and other new and unique characteristics of network have provided a huge commercial value to enterprises.

\section{IMPACTS OF CUSTOMER PARTICIPATION ON BRAND LOYALTY}

The research on the results of customer participation behavior tends to believe that customer participation is an important factor that influences their loyalty (Cermak et al. 1994; Schouten et al. 2007). There aren't much extant researches that had focused on the impact of customer participation behaviors on brand loyalty. Schouten et al (2007) discussed that consumers who have joined the brand community and obtained the extraordinary experience would establish a closer relationship with products, brands, companies and other consumers of same types, and that would build a strong community identity and a sense of community and lead to an enhanced brand recognition and loyalty.

Customer participation in community has a positive impact on the behaviors of recommending to others and active participation in group activities. While a higher pressure from the community could lead to a rejection tendency, which will not only 
significantly reduce customers' willingness of continuous participation in the community, but also reduce the willingness to be loyalty to the brand (Algesheimer, and Dholak 2005). Compared with other internet virtual communities, Wechat is taking point to point or one to one information dissemination. Wechat is characterized with privacy, and its communication range mainly covers circle of friends and public information accounts. Therefore, Wechat's information system is different from the traditional one, which enables Wechat to focus on customer participation, mass psychological demands, and put emphasis on the capability of personal experience and word-of-mouth. Therefore, there is a necessity to have further exploration of the impacts of customer participation on brand loyalty when conducting a public relations campaign via Wechat.

\section{SIGNIFICANCE, LIMITATION AND FURTHER RESEARCH DIRECTION}

The study combined the factors of Wechat media characteristics with the consumers' participation behaviors from the perspective of the consumers in China and explored the role of these factors in affecting customer participation behaviors and also their impact on brand loyalty.

We believe that the different media characteristics of Wechat have some certain impact on customer participation in the public relations campaign, at the same time; the customer participation behaviors of Wechat have a positive impact on the brand loyalty. Therefore, the customer participation behaviors in the Wechat public relations campaign are different from those in the production and service industries. Therefore, enterprises and government agencies should choose rational means and methods to improve the consumers' intention of participation which would lead to an enhanced consumer brand loyalty. In the China's mobile internet environment, customers' behaviors differ in accordance with industries and there is a necessity to have further investigation and analysis of the scale development and examination. In future, to make the research more pertinent, a comparison study of moderating effects of examinees will be conducted, taking into considerations of the factors such as different industries, ages, circles of the people. This study put forward a theory model of customer participation based on media characteristics of Wechat; these assumptions need to be confirmed by further empirical analysis, this is also direction of our subsequent research.

\section{ACKNOWLEDGEMENTS}

Funded Project: "Twelveth Five years Planning" (2014) research project of Jiangxi Social Science, 14GL27; Jiangxi Universities Humanities and Social Sciences Research on Young Fund, GL1412.

\section{REFERENCES}

[1] Alison E.Lloyd. (2003), "The Role of Culture on Customer Participation in Services". HongKong Polytechnic University

[2] Ariely D. (2000), "Controlling the Information Flow: Effects on Consumers' Decision Making and Preferences," Journal of Consumer Research, 27(2), 233- 248.

[3] Baliantine, P.W, Martin, A.S. (2005), "Forming Parasocial Relationships in Online Communities," Advances in Consumer Research, 32(2), 197-201.

[4] Banczyk,B., Krmer,N., Senokozlieva,M, (2008), "The wurst' meets 'fatless' in MySpace: The relationship between self-esteem, personality, and self-presentation in an online community," Paper presented at Conference of the International Communication Association, Montreal, Quebec, Canada.

[5] Cermak,D,S.P.,File,K.M.,Prince,R.S. (1994), “Customer participation in service specification and delivery," Journal of Applied Business Research,( 2), 90- 100.

[6] Choi, Eunjeong(2013), "KakaoTalk, a mobile social platform pioneer,'SERI Quarterly,6(1), 63-69.

[7] Claycomb,C.,Lengnick-Hall,C.A.,Inks,L.W. (2001), "The customer as a productive resource: a pilot study and strategic implications," Journal of Business Strategies, (1), 47-68.

[8] Choi, D., Kim,J. (2004), "Why People Continue to Play Online Games: In Search of Critical Design Factors to Increase Customer Loyalty to Online Contents," Cyberpsychology \& Behavior,7(1),11-24.

[9] Davis F D, Bagozzi R P, Warshaw P R. (1992), "Extrinsic and intrinsic motivation to use computers in the workplace," Journal of Applied Social Psychology, 22, 1111-1132.

[10] Ellison, N., Steinfield, C., Lampe, C. (2007), "The benefits of Facebook 'friends': Social capital and college students use of online social network sites," Journal of Computer-Mediated Communication, 12(4), 1143-1168.

[11] Ennew,C and Binksm,R. (1999), "Impact of Participative Service Relationships on Quality, Satisfaction and Retention: An Exploratory Study," Journal of Business Research, 46,121-132.

[12] Fang, Eric (2008), "Customer participation and the tradeoff between new product innovativeness and speed to market," Journal of Marketing, 72(4), 90-104.

[13] Flore,A.M.,Kim, J.,Lee, H.H. (2005), "Effect of Image Interactivity Technology on Consumer: Responses Toward the Online Retailer," Journal of Interactive Marketing, 19(3),42-62.

[14] Goldsmith, R. (2002), "Viral Marketing: Get Your Audience to Do Your Marketing for You," New York: Financial Times Management.

[15] Kozinets, R. V., K. de Valck, A. C., Wojnicki and S. J.S. Wilner, (2010), "Networked Narratives: Understanding Word of Mouth Marketing in Online Communities," Journal of Marketing, 74, p.71-89. 
[16] Lampe, C., Ellison, N., Steinfield, C.(2006), "A Face (book) in the crowd: Social searching vs. social browsing," Proceedings of the 2006 20th anniversary conference on Computer Supported Cooperative Work, 167-170.

[17] Lipsman, A., Mudd, G., Rich, M., Bruich, S. (2010), "The power of 'Like': How brands reach (and influence) fan through social-media marketing," Journal of Advertising Research, 52(1), 40-52.

[18] Lusch, R. F., Vargo, S. L. (2006), "Service-dominant logic: reactions, reflections and refinements," Marketing Theory, (3), 281- 288.

[19] Mathwick, C., (2002), "Understanding the Online Consumer: A Typology of Online Norms and Behaviour," Journal of Interactive Marketing 16 (1), 40-55.

[20] Moon,J.,Y. Kim (2001), "Extending the TAM for a World-Wide-Web Context," Information \& Management, 38, 217-230.

[21] Nambisan, S., Baron, R. (2009), "Virtual Customer Environments: Testing a Model of Voluntary Participation in Value Co-creation Activities," Journal of Product Innovation Management, 26,388-406.

[22] Rodie, A. R. and S. S. Kleine (2000), "Customer Participation in Service Production and Delivery," in Handbook of Services Marketing and Management, Teresa A. Swartz and D. Iacobucci (Eds.), Thousand Oaks, CA: Sage Publications, 111-125.
[23] Schouten J W, McAlexander J H, Koenig H F. (2007), "Transcendent Customer Experience and Brand Community," Journal of the Academic Marketing Science, 35( 3), 357- 368.

[24] Sun S. Y, Lee J. H, Jung Y. J, Lee S. H. (2011), "Theses: Case Study of SNS (Social Networks Service) Application on Fashion Corporate; Focused on Twitter," Korea Society of Fashion Business, 15(1): 158-157.

[25] Trusov, M., Bucklin, R.E., Pauwels, K.(2009), "Effects of word-of-mouth versus traditional marketing: Findings from an internet social networking site," Journal of Marketing, 73(5),90-102.

[26] Vargo, S., Lusch,R.(2004), "Evolving to a New Dominant Logic for Marketing," Journal of Marketing, 68(1),1-17.

[27] Varnali, K., Toker, A. E.(2010), "Mobile marketing research: The state of the art,"International Journal of Information Management ,(3).

[28] Weiss, A. M., Lurie, N. H., Macinnis, D. J. (2008), "Listening to strangers: whose responses are valuable, how valuable are they, and why," Journal of Marketing Research, 45(4), 425-436.

[29] Williams, R. L.,Cothrel, J. (2000), "Four smart ways to run online communities," Sloan Management Review, 41 (4), 81-91.Web of Science ${ }^{\circledR}$ Times Cited: 27

[30] GlobalWebIndex (2013), "WeChat Came to the Fifth in the World App Rank in July," http://www.chinainternetwatch.com/category/socialmedia/social-network/ 